REVIJA ZA ELEMENTARNO IZOBRAŽEVANJE JOURNAL OF ELEMNTARY EDUCATION

Vol. 11, No. 4, pp. 341-356, December 2018

\title{
DAILY PHYSICAL ACTIVITY OF SAAMI PRIMARY SCHOOL CHILDREN IN NORTHERN NORWAY
}

\author{
ØYVIND BøTHUN ${ }^{1} \&$ HeRBERT ZOGLOWEK ${ }^{2}$ \\ ${ }^{1}$ UiT - The Arctic University of Norway, Campus Alta, School of Sport Science
${ }^{1}$ UiT - The Arctic University of Norway, Campus Alta, School of Sport Science \\ CORRESPONDING AUTHOR/KORESPONDENČNI AVTOR \\ herbert.zoglowek@uit.no
}

Potrjeno/Accepted

28. 11. 2018

Objavljeno/Published

20. 12. 2018

Keywords:

WHO

recommendation, activity measurement, moderate-to-vigorous physical activity, sedentary lifestyle.

Ključne besede: priporočila svetovne zdravstvene organizacije - WHO, merjenje dejavnosti, zmerna do živahna telesna dejavnost.
Abstract/Povzetek The primary aim of the study was to measure and compare daily physical activity among young people in the most northern part of Europe where the ethnic minority, the Saami people. The research population was 6-, 9- and 15-year old children in Saami majority municipalities $(\mathrm{N}=180)$. In this article, we present and discuss the results of a cross-sectional study of physical activity among children of primary school age. . No significant differences were found when results were compared with the same age group throughout Norway, or in other European countries. The results in total indicate that global trends towards a comfortable, rather sluggish lifestyle will not stop, even when the local and regional conditions favour a different, more active and health-promoting lifestyle.

Dnevne telesne dejavnosti samijskih šolarjev s severa Norveške Cilj študije je bil izmeriti in primerjati dnevne telesne dejavnosti mladih $\mathrm{v}$ najsevernejšem delu Evrope, kjer živijo pripadniki etnične manjšine, ljudstva Sami. Raziskovalna populacija so bili 6, 9 in 15 let stari otroci v samijski osnovni šoli $(\mathrm{N}=180)$. $\mathrm{V}$ članku predstavljamo in obravnavamo rezultate medsektorske raziskave telesne dejavnosti osnovnošolskih otrok, pri čemer $\mathrm{v}$ primerjavi z drugimi otroki iste starostne skupine na Norveškem ali v drugih evropskih državah ni bilo mogoče najti pomembnih razlik. Rezultati v celoti kažejo, da se globalni trendi v smeri udobnega, precej počasnega življenjskega sloga ne bodo ustavili tam, kjer bi lokalni in regionalni pogoji dajali prednost bolj dejavnemu in zdravemu življenjskemu slogu.

UDK/UDC

796:373.3-

$053.5(481.7)$

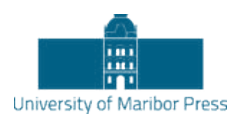




\section{Introduction}

Physical activity is a complex phenomenon that can be defined as any body movement produced by skeletal muscles that requires energy expenditure. It is not the same as physical training, though training can be a form of physical activity, along with working, playing, carrying out household chores, travelling and engaging in recreational pursuits (WHO, 2010). Physical activity can form part of everyday life, for instance by moving from one place to another; part of a person's work; part of their leisure time, and finally, it is a health-promoting factor. This latter aspect is particularly important during the growth and development phases in childhood and adolescence.

Since, in general, the proportion of low-activity activities has steadily increased, and insufficient physical activity is recognized worldwide as one of the leading risk factors for death, the WHO felt obliged to give recommendations for a level of daily physical activity time that has a health-promoting effect. One of the recommendations for children and adolescents aged 5 to 17 years is that they should do at least 60 minutes of moderate-to-vigorous physical activity (MVPA) daily (WHO, 2010; Directorate of Health, 2014a).

The status of physical activity in Norway reveals what is, in a way, a paradoxical situation: on the one hand, the living conditions in Norway have become more and more leisure-friendly. Cities, municipalities and the state spend enormous resources to provide and extend opportunities for movement and active play, especially for children and adolescents. Schools and many sports organizations offer a varied range of physical activities, and annual reports show that $93 \%$ of children and adolescents are or have been members of a sport club (Norges Idrettsforbund, 2016). On the other hand, natural physical activity, i.e. movement in everyday life, has been diminishing among children and adolescents in recent decades in a way that has been alarming those responsible for public health for years. The Directorate of Health survey shows that children and adolescents in Norway rest more than they once did and spend less time on physical activity (Andersen et al., 2012). It seems that the overall physical activity level is worryingly low, perhaps with the exception of the youngest members of the population. Several surveys show that children and adolescents in Norway spend more time on sedentary and screen-based activities than the corresponding group did 10 and 20 years ago 
(Directorate of Health, 2014b). Viewed from a public health perspective, this is one of the major challenges for the (health) future of children and young people.

Most likely, one reason for this development is attributable to structural changes in society that contribute to reducing physical activity requirements in daily life. Even though Norwegians spend more time on workouts and training, everyday activity has been reduced. This has resulted in large groups of the population being characterized as inactive. The car replaced the bicycle. A modern family often has two cars for all its activities (Vaage, 2009). This trend also appears among children and adolescents. They live a more sedentary life than they did a few decades ago. Internet, computer games, TV, smart phones, driving to and from school and leisure activities are to blame for this. It seems that there is less time for free play in the everyday lives of children and young people. Norwegian boys between the ages of 11 and 16 often spend 40 hours a week in front of various monitors. Girls are even less physically active than boys. Measurement of physical activity shows that pupils in Oslo schools are more active during school time than in their leisure time (Andersen, 2008). At the same time, physical education in school is under pressure. The demand for increased knowledge in other subjects repeatedly calls into question the need for (more) sports lessons, even though physical education is often the only opportunity for many children to engage in versatile activity.

Based on recommendations from the WHO on the health-enhancing levels of activity, Norway is at about the same level as other European countries. This means many young people do not reach the health-enhancing level of $60 \mathrm{~min} /$ day of moderate-to-vigorous physical activity (MVPA) (WHO, 2010, p.20), despite their partly high participation in sports. The results of the WHO study with self-reported data show that only $15 \%$ of 15 -year-olds in Europe reach this minimum recommendation (Currie et al., 2012). In the questionnaire, MVPA was defined as "any activity that increases your heart rate and makes you get out of breath some of the time" (Currie et al., 2012, p.129). The self-reporting of Norwegian pupils on this matter indicates about $9 \%$ of girls and $12 \%$ of boys. That is below the European average.

The Norwegian School of Sport Sciences, in cooperation with the Norwegian Institute of Public Health, has conducted two large surveys (ungKan1 (2005-2006) and ungKan2 (2011-2012)) of physical activity levels and activity habits, on a representative sample of 3000 children and adolescents. The results of the last 
survey (2011-2012), based on another method, show better results than in the European survey. Approximately 50\% (43\% of girls and 58\% of boys) in the group of 15 -year-olds fulfil the recommendation of minimum moderate physical activity for $60 \mathrm{~min} /$ day (Andersen et al., 2012). In addition, and as an extension of these national studies, the purpose of our survey is to map current activity habits among 6-, 9- and 15-year-olds in Saami majority municipalities. The Saami people are an ethnic minority living in northern Norway, a situation which, not least because of their nomadic-peasant tradition, has instilled in them a special relationship with nature and nature-related activities. The purpose of this paper is to describe the movement situation and activity patterns of pupils of an ethnic minority in Europe, particularly their daily level of activity, to identify possible sociodemographic differences by gender and age, and compare these with data from the rest of the country.

\section{Method}

\section{Design}

The method used in this study is a cross-sectional survey. The survey is based on two different sets of data. The first data set was collected by questionnaire, the second by activity measurement, with the use of an accelerometer. Because of the particular character of the issue, it was considered necessary to perform a triangulation to compensate for some disadvantages of each method. For example, although the accelerometer has been thoroughly tested for validity and reliability (Hansen, 2013), one disadvantage is that it cannot be used in water. The activity gauge can say a lot about the activity level and activity pattern, regardless of the types of activities. On the other hand, self-reported data can have some weaknesses in objectivity, thus hindering objective measurement.

The participants wore the accelerometer around their bodies for seven consecutive days. The questionnaire about the pupils' leisure and activity habits was answered at school.

This design provides important information on both physical activity and sedentary lifestyles, and makes it relatively easy to calculate statistically where the respondents are in relation to the recommended levels of daily physical activity. 


\section{Participants}

The researchers applied the same selection criteria as those of the 2011-2012 national study ungKan2 (Andersen et al., 2012). Various differentiations were made in this national study, but the ethnic minority of the Saami has not been specifically studied or examined. Therefore, special attention is paid to pupils in four Saami majority municipalities. The data was obtained from primary school pupils, more precisely 6-, 9- and 15-year-olds from Kautokeino, Karasjok, Tana and Porsanger (see Fig.1). Both the survey and the activity measurement test were conducted in the 2014/2015 school year. According to school enrolment lists (Statistics Norway, 31.08.2014), it includes 414 pupils in total.
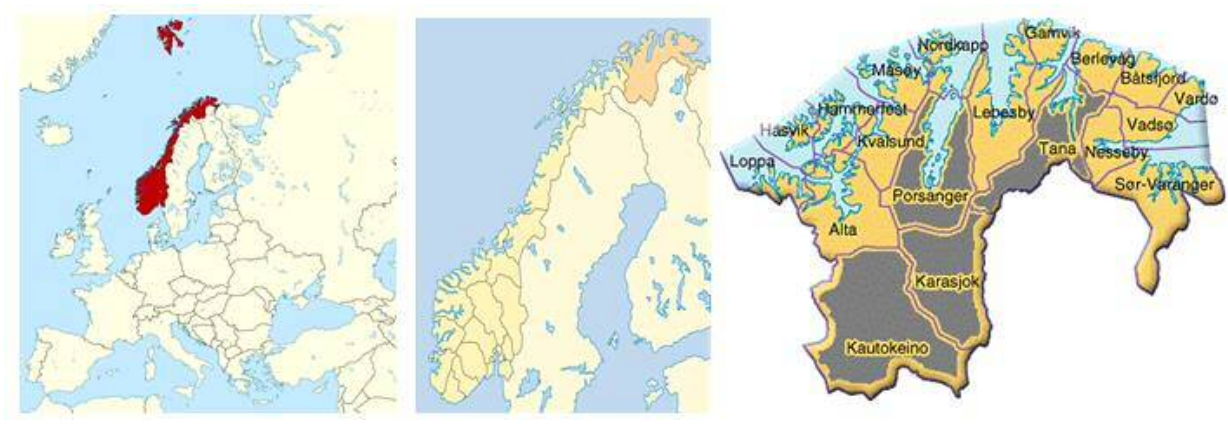

Figure 1: The Saami majority municipalities in Finnmark.

Participation was voluntary, upon approval by school authorities and written consent of the parents. One hundred and forty-one pupils participated in the activity measurement and 180 pupils in the survey (see Table 1).

Table 1: Total number and percentage of participating pupils

\begin{tabular}{lcccc}
\hline & Age 6 & Age 9 & Age 15 & Total \\
\hline Kautokeino & 38 & 33 & 34 & 105 \\
\hline Karasjok & 27 & 36 & 39 & 102 \\
\hline Tana & 24 & 29 & 38 & 91 \\
\hline Porsanger & 37 & 36 & 43 & 116 \\
\hline Invited to participate (sum) & 126 & 134 & 154 & 414 \\
\hline Positive answer and included in the survey & 43 & 69 & 68 & 180 \\
\hline Participation percentage & $34.1 \%$ & $51.5 \%$ & $44.1 \%$ & $43.5 \%$ \\
\hline
\end{tabular}




\section{Procedures and analysis}

After receiving letters of agreement, the contact persons at the schools contacted the teachers and the participants to conduct the survey. The pupils could choose to answer in Norwegian or Saami; the youngest pupils were helped to understand and to fill out the survey. The use of the accelerometer was explained; it was then placed on the left hip of all participating pupils. The accelerometer was to be used all the time for seven days, except when sleeping or when the body was in contact with water.

\section{The accelerometer}

The accelerometer is a small electronic monitor that is attached to the body with an elastic belt. It measures all physical activity and movement. It can be worn around the body without affecting the person's natural movement pattern. The accelerometer detects all motion to which it is exposed, and it filters out activity that is beyond natural human movement. The measuring device was pre-set to certain settings, which were similar to those used in the national study (Andersen et al., 2012). It was to measure physical activity for seven days, every day from 06:00 until 24:00. The epoch period was 10 seconds (every 10 seconds the activity level was measured). Activity measurement began the day after the device was handed out to the participants.

The accelerometer also has a built-in clock, which allows time-setting and recording. This also means that subsequent analysis can view activities on certain days or at particular times of the day. For statistical analysis, the accelerometers were added to the ActiLife software (ActiGraph, Pensacola, FL, USA).

\section{Health-enhancing level of activity}

The main aim of this study was to determine whether participants met the recommendation of the Norwegian Directorate of Health. In order for the physical activity to be registered within the recommendation, it must be of moderate or vigorous intensity (Directorate of Health, 2014a). Activity levels were placed in different categories based on the number of counts recorded per minute. The limit values for the categories were identical to those used by the Norwegian Directorate of Health (Andersen et al., 2012). In order for the activity to fall within the recommendation of the Directorate of Health, it must be considered as at least 
moderate. To identify who meets the recommendation for physical activity, the number of minutes with over 2000 counts per minute were summed and then divided by the number of days with valid meter registrations. If daily minutes of physical activity of at least moderate intensity exceeded 60, it was considered that the person had satisfied the recommendation. This operationalization of the recommendation for physical activity corresponds to the need for a certain amount of physical activity to achieve health benefits (Hansen, 2013). Table 2 shows the division between different activity categories.

Table 2: Limit values of counts per minute and physical activity categories (Andersen et.al., 2012).

\begin{tabular}{lll}
\hline \multicolumn{1}{c}{ Category } & \multicolumn{1}{c}{ Counts per minute } & \multicolumn{1}{c}{ Example of activity } \\
\hline Inactive & $0-99$ & $\begin{array}{l}\text { Driving a car, watching TV, playing } \\
\text { computer games }\end{array}$ \\
\hline Light intensity & $100-1999$ & $\begin{array}{l}\text { Walking slowly, playing with children or } \\
\text { doing housework }\end{array}$ \\
\hline Moderate intensity & $2000-5999$ & Walking briskly or easy running \\
\hline Vigorous intensity & 6000 or more & $\begin{array}{l}\text { Running, swimming or cycling } 15 \mathrm{~km} / \mathrm{h} \text { or } \\
\text { more, sports activities }\end{array}$ \\
\hline
\end{tabular}

Criteria for inclusion in the statistical analysis: A day was valid if activity was registered for at least 8 hours, and there had to be a minimum two valid registration days.

\section{Questionnaire}

The questionnaire is, in large part, taken from the national study ungKan 2 (Andersen et al., 2012). It aims at mapping physical activity habits, transport habits and time spent in front of screens. Most of the questions were identical; those that were not necessarily relevant to this study were removed, and questions that were needed to address our issues were added. In addition, questions were related to local activities that are specific to the region. These concerned participations in reindeer breeding, racing, ice fishing and various snowmobile activities.

The questionnaire consisted of 18 questions with closed response options. The questionnaire was standardized and similar for all pupils. The collected material was later read and processed using the SPSS software.

\section{Analysis}

The analysis brought together the recommended activity level and the actual level of the sample. Data from the questionnaire and from the activity measurement were 
connected to each other in SPSS. This was done by assigning a number to both the questionnaire and the measurement pertaining to a given person. To determine how age and gender were distributed to satisfy the recommendation, these variables were cross-tabled. Potential correlations between groups satisfying the recommendation and other variables like gender, age, participation in sports teams, screen time and an active route to school were tested using the Chi-square test. Differences between groups were tested with variance analysis or the general linear model (GLM), where univariate analysis was used. The significance level was set to 0.05. All statistical analysis was performed using IBM SPSS for Windows, Version 21.0 Software.

\section{Results}

\section{Physical activity - activity measurements}

The analysis presented in Figure 2 shows that $82.4 \%$ of 6 -year-olds, $65.6 \%$ of 9 year-olds and $40.4 \%$ of 15 -year-olds satisfy the recommendation for at least 60 minutes of MVPA a day. There is a significant difference between the age groups with respect to attainment of the recommendation (Chi-square $=16.1, \mathrm{p}<0.001$ ). Less than half the 15-year-olds reach the recommended level, compared with the 6-year-olds. If we look at the entire sample $(\mathrm{N}=141)$, we can see that $2 / 3$ of the boys and slightly more than the half the girls meet the recommendation of the Directorate of Health (67.1\% and 53.5\%, respectively). Even though in all age groups there are more boys than girls who fulfil the recommendation, a significant connection cannot be recognized (Chi-square $=2.7, \mathrm{p}=0.09)$.

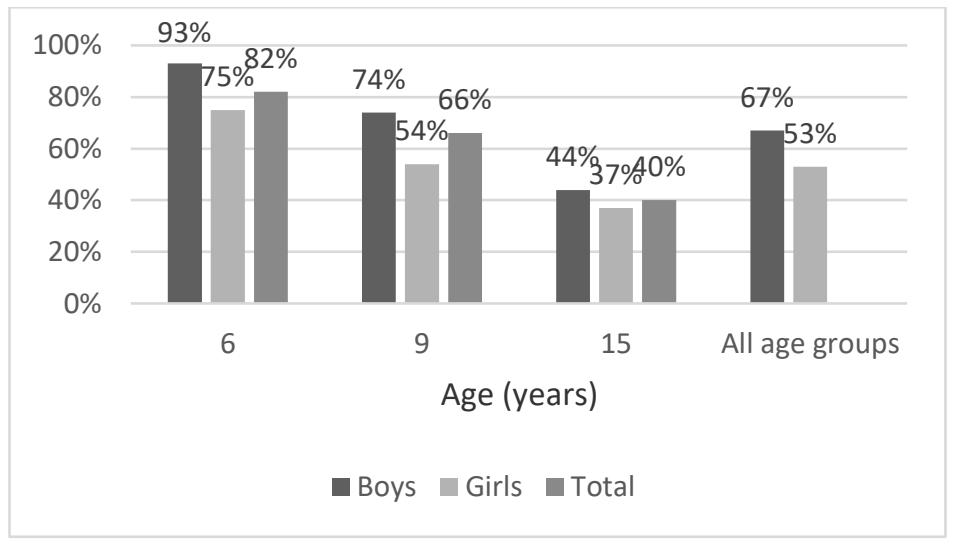

Figure 2: Percentage that satisfies recommendation, by age and gender 


\section{Intensity-specific physical activity}

Figure 3 shows how much time during the day different age groups devoted to different intensity categories. Not surprisingly, the youngest spent a greater proportion of their time on moderate and high intensity activities than did the older ones. It is clear that the proportion spent on idle time increases with age. All groups are idle for more than half the day (sleeping time is not included). Much of the day usually goes to sedentary activities at school, homework, meals and more. It is therefore not surprising that most of the day is inactive. It is definitely noteworthy that 15 -year-olds spend over $70 \%$ of the day on being more or less completely at ease, without healthy movement.

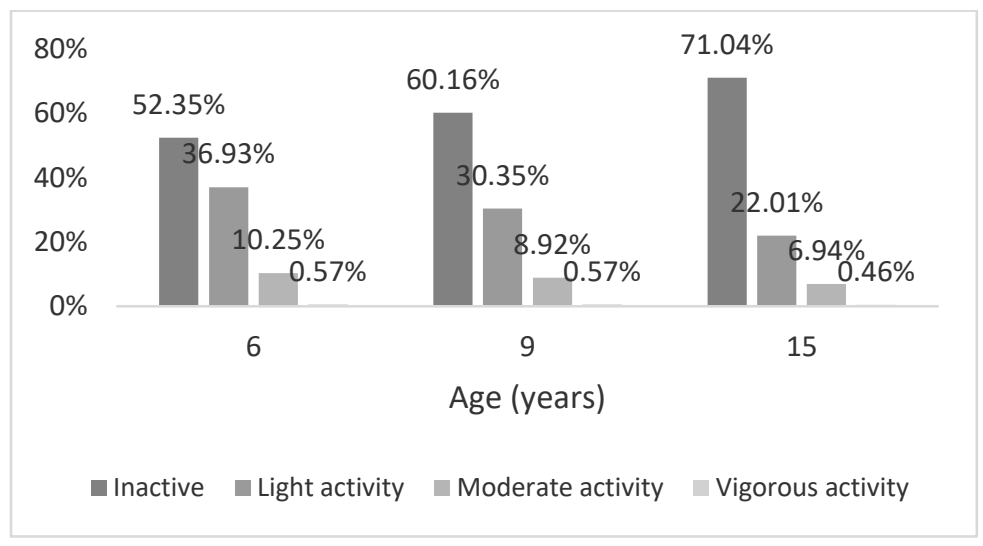

Figure 3: Percentage of the day spent in the different activity categories.

\section{Comparison with the national survey}

The National Representative Survey UngKan 2 shows that activity levels and activity patterns among 6-year-olds are such that most boys meet the recommendation (Andersen et al., 2012). In our survey, this group is also shown to be the most active. Overall, comparing the percentages with those from the national study, the Saami pupils perform less favourably. The tendency to physical inactivity increases for both groups, but is much stronger for the Saami pupils. The proportion of boys in Saami majority municipalities who satisfy the recommendation differs by $20 \%$ between 6 -year-olds and 9 -year-olds, and by $30 \%$ from 9 -year-olds to 15 -year-olds. The result is the same as on the national level, but the downward trend that comes with growing age is stronger in our survey. In all age groups, the girls fare much worse. 


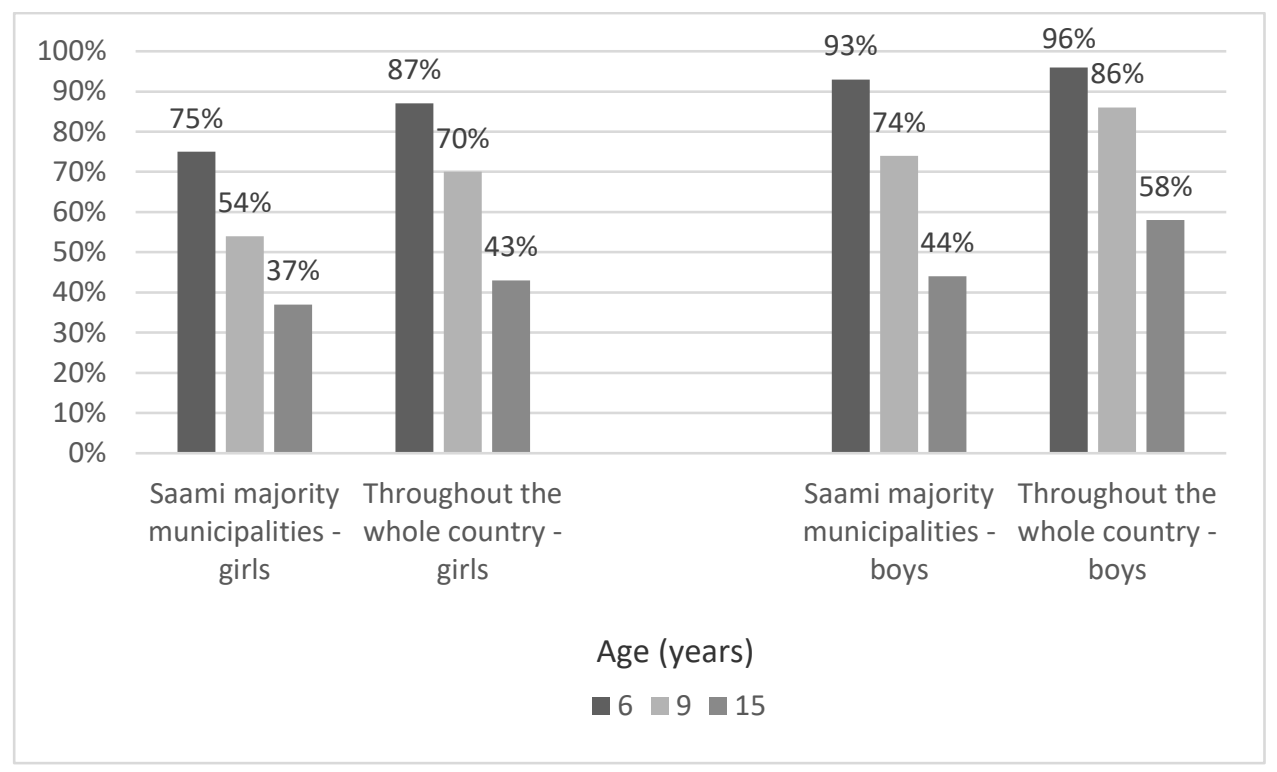

Figure 4: Proportion of boys and girls who satisfied the recommendation in Saami majority municipalities and throughout the country.

\section{Recreational Activities}

Figure 5 shows the percentage of those who reported membership in sports clubs. No connection was found between gender and membership in sports clubs (Chisquare $=0.027, \mathrm{P}=0.87)$. There wa, however, a connection between age group and membership in sports clubs (Chi-square $=9.34, \mathrm{P}<0.01)$.

In the oldest group, we found that every second pupil was a member of a sports club. In the group of 6 -year-olds, $70 \%$ were recruited by sports clubs. This percentage increased to $83 \%$ among 9-year-olds, owing mainly to an increase among girls. Between the ages of 9 and 15, the percentage of membership decreases to $58 \%$. There are relatively more girls than boys active in sports clubs. Whether membership in a sports club increases the daily level of activity is shown in Figure 6. There is a clear correlation between membership in a sports club and fulfilling the physical recommendation (Chi-square $=8.55, \mathrm{p}=0.003$ ). Particularly in the group of 15-year-olds, we can see that every second adolescent who is a member of a sports club fulfils the recommendation, while only every fifth pupil who is not a member of a sports club does 60 minutes of physical activity per day. 


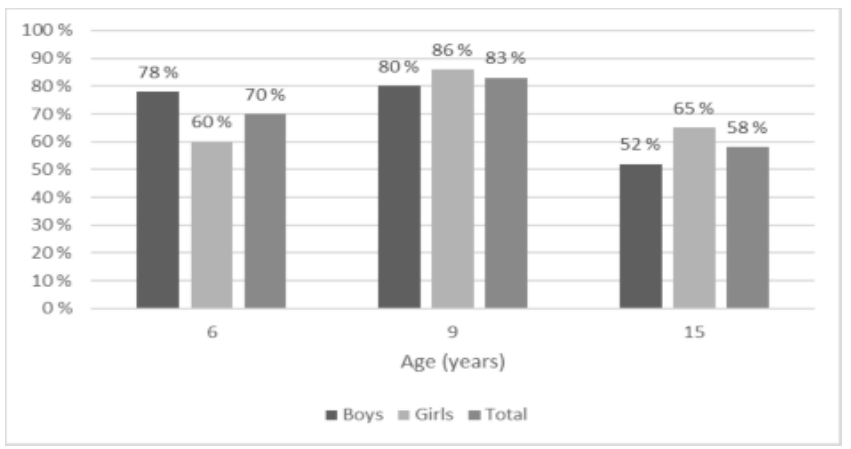

Figure 5: Percentage that is a member of a sports club, by gender and age.

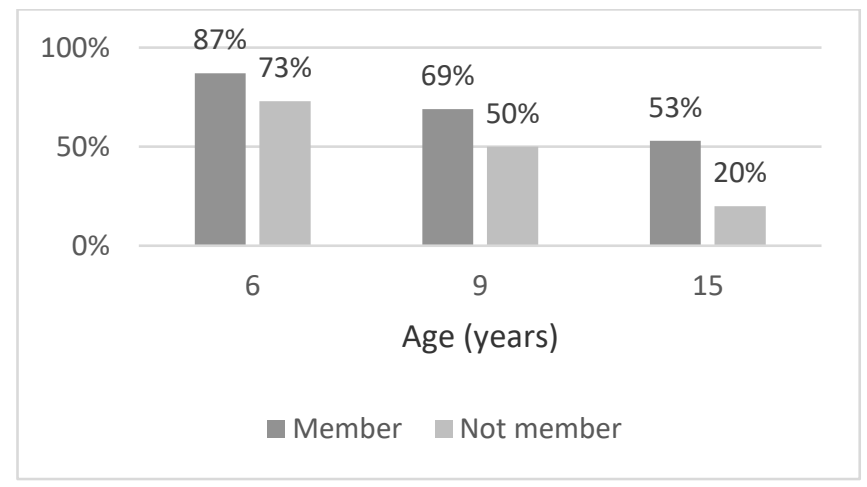

Figure 6: Percentage that reaches the recommendation among those who are members in total, and those who are not members.

\section{Physical activity and transport to school}

One question in the questionnaire gave information about whether the pupils had an active or passive route to school. In this case, $22.3 \%$ (23.3\% boys and $21.3 \%$ girls) answered that they mostly walked, cycleed or skied to school. Without going into details with regard to sub-variables (season or distance), it can be said that the same tendencies are apparent. There is no significant correlation between the manner of getting to school and meeting the recommendation (Chi-square $=0.10$, $\mathrm{P}=0.74$ ). 


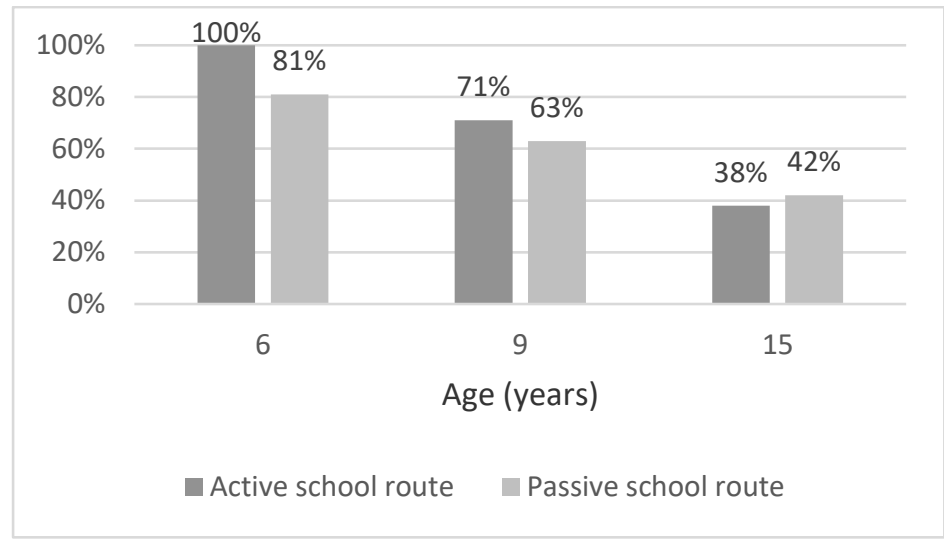

Figure 7: Percentage that reaches the recommendation among those who have active or passive school routes.

Nevertheless, two findings are interesting, as shown in Figure 7: the first is that all 6 -year-old pupils who had an active school route fulfil the recommendation. However, it should be said that the absolute number of such pupils is so small $(\mathrm{N}=2)$ that the informative value is also extremely low. The second is that in the group of 15 -year-old pupils, less of those who have an active school route $(38 \%)$ fulfil the recommendation, compared to those who have a passive school route $(42 \%)$.

\section{Discussion}

The main objective of this study was to look at the physical behaviour and activity patterns of young Saami pupils, from an ethnic minority in Northern Norway. Are there differences in comparison to the rest of Norwegian children and adolescents? When comparing our results with the national survey Ungkan 2 (Andersen et.al. 2012) and selected data from international studies (WHO, 2009), most findings were similar, while some were contradictory. When we consider daily movement time as an indicator, there is a tendency for Saami children to be less physically active than Norwegian children in general. However, we can only consider this a tendency because no significant difference is visible. The same applies to gender differences: girls are less active than boys, but this difference is also insignificant. 
The tendency to inactivity increases with age. While more than $90 \%$ of 6 -year-old boys show a satisfactory range of movement, this value drops over the course of nearly 10 years (by almost $50 \%$ by the age of 15). It seems that the reduction in daily physical activity time does not occur linearly with respect to age and gender, and the percentage drop is not equally marked in both groups: while the number of inactive Saami boys goes down by $49 \%$, from the age of 6 to the age of 15 , inactivity among Norwegian boys only increases by $38 \%$. In the case of girls, there is a contrary development: the proportion of inactive Saami girls increases by $38 \%$, but among Norwegian girls in general by $44 \%$. One more difference can be observed: in the case of Saami girls, the drop between the 6-year-olds and the 9-year-olds is larger than that between the 9 -year-olds and the 15 -year-olds $(21 \%$ to $17 \%)$. This trend is opposite for Norwegian girls (17\% to $27 \%$ ). In the case of boys, the easing tendency points in the same direction, albeit with a great degree of inequality. As already mentioned, it is substantially more marked between 9-year-olds and 15-yearolds (30\% Saami and 28\% Norwegian) than between 6 -year-olds and 9-year-olds (19\% Saami and 10\% Norwegian).

The number of inactive girls' increases by 38\% over the entire period. This is less than in the case of boys; however, since only $75 \%$ of 6 -year-olds reach the recommended daily activity time, the actual number of active 15 -year-old girls is only $37 \%, 7 \%$ less than for boys at this age. In other words, only every third 15 year-old girl enjoys minimum moderate daily activity of at least 60 minutes.

This result seems somewhat frightening, considering that just over half of 15-yearold girls are members of sports clubs, which means they are active in the sports club at least two or three times a week. Overall, membership in sports clubs, both among the Saami and on a national scale, is somewhat lower than in other European countries (c.f. WHO, 2009, Lamprecht et al., 2008, 2015, Manz et al., 2015, Kühnis et al., 2016). Peak membership in sports clubs occurs at age 9. The objective numbers obtained through daily physical activity measurement show that membership in sports clubs does not necessarily affect daily movement time. However, we must also take into account that some sports were recorded insufficiently or not at all by the measuring equipment (e.g. swimming or ski jumping). Perhaps the research period (November until January, i.e. wintertime) may also have influenced the results. 
We can also show (Fig. 3) that the 6- and 9-year-old pupils are idle for more than half the time during the day, and 15-year-olds for nearly three-quarters of the day. These percentages seem alarming. Health promoting activity (MVPA) can only be registered at 10\% among 6 -year-old pupils, and in the other age groups, this figure is even lower.

An active or passive method of reaching school also seems to have little effect on the level of activity. Almost one in four Saami pupils reaches the school in a physically active way (walking, cycling or skiing). However, the health-promoting effect is relatively low. Indeed, all 6-year-olds reach moderate activity for the recommended 60 minutes, but the absolute number is too small to be able to reach definite conclusions. Interestingly, in the case of 15-year-old pupils, fewer students with an active route to school fulfil the recommendation than those with a passive route to school.

\section{Conclusion}

The major advantage of this study is that we had access to the total population of pupils in Saami majority communities. That was necessary because of the peculiarity of the instrumentation and the youth of more than a quarter of the total population. That at least $43.5 \%$ of the total population fulfilled the participation criteria gives the study a relatively large scope of validity. The residential area of the Saami in Norway is only a small area in the extreme north of Europe, but the lifestyle and movement behaviour hardly seem to differ from those in the rest of Europe. At least in comparison with pupils in Norway, no significant difference can be identified. For deeper, causal interpretations and conclusions, the prerequisites are missing because of the cross-sectional design. For this purpose, longitudinal studies, in different seasons of the year, would be needed to examine and assess individual as well as group development.

Two concluding remarks should be made, addressing both the specific local situation and the global perspective. For a country like Norway, which has a strong connection to nature and advocates friluftsliv (outdoor recreation) as a lifestyle related to nature and movement, and for the Saami, who are considered a very nature-loving people, these results could be surprising. In this respect, it can be stated that the children in the northernmost part of Europe do not differ from other 
European children in their level of everyday physical activity and their range of movement.

At the same time, inherent problems emerge: the pupils in the Saami majority municipalities have too little physical activity in their everyday life. Far too few fulfil the WHO recommendation of a minimum 60 minutes of moderate activity per day. The great need for physical activity, inherent in all children, is often replaced by sedentary and less health-promoting activities. In addition, similar to developments in other European countries, inactivity increases with age. The age group of 15year-olds should therefore be considered as among the most important targets for activity promotion programs. From the point of view of physical education and, above all, public health, children and especially adolescents in the Saami municipalities, should be offered more activity programs at school as well as in cultural and recreational areas.

\section{References}

Andersen, S. (2008). Fysisk aktivitet blant barn og unge $i$ Norge: en kartlegging av aktivitetsnivå og fysisk form hos 9- og 15-åringer. Oslo: Helsedirektoratet i samarbeid med Norges idrettshøgskole.

Andersen, S., Kolle, E., Stokke, J. S. \& Hansen, B. H. (2012). Fysisk aktivitet blant 6-, 9- og 15-airinger i Norge: resultater fra en kartlegging i 2011. Oslo: Helsedirektoratet.

Bøthun, Ø. (2015). Aktiv eller parkert ungdom? En studie av fysisk aktivitet, aktivitetsniva a og stillesitting blant 6-, 9- og 15-äringer i samiske majoritetskommuner (masterthesis). Alta: UIT (unpublished).

Currie, C., Zanotti, C., Morgan, A., Currie, D., de Iooze, M., Roberts, C., Samdal, O., Smith, O. \& Barnekow, V. (eds.) (2012). Social determinants of health and well-being among young people. Health behavior in School-aged Cbildren (HBSC) study: international report from the 2009/2010 survey. Copenhagen: WHO Regional Office for Europe (Health Policy for Children and Adolescents, No.6).

Directorate of Health (2014a). Anbefalinger om kosthold, ernaring og fysisk aktivitet. Available: http://www.helsedirektoratet.no/Lists/Publikasjoner/Attachments/806/Anbefalingerom-kosthold-ernering-og-fysisk-aktivitet-IS-2170.pdf. Accessed October 12 2918.

Directorate of health (2014b). Fysisk aktivitetsniva blant voksne og eldre $i$ Norge. Oppdaterte analyser basert på nye nasjonale anbefalinger $i 2014$ (IS-2183). Available: http://helsedirektoratet.no/publikasjoner/fysisk-aktivitetsniva-blant-voksne-og-eldre-i-norge/Sider/default.aspx. Accessed October $12^{\text {th }} 2018$.

Hansen, B. H. (2013). Physical activity in adults and older people: levels of objectively measured physical activity in a population-based sample of Norwegian adults and older people (20-85 years). Oslo: Norwegian School of Sport Sciences. 
Kühnis, J., Wachter, B. \& Frommelt, C. (2016). Involvement in Sports Clubs and Informal Sport Activities of Primary and Secondary School Children in Liechtenstein. Journal of Elementary Education 9 (1-2), 11-19.

Lamprecht, M., Fischer, A., Wiegand, D. \& Stamm, H. (2015). Sport Schweiz 2014: Kinder- und Jugendbericht. Magglingen: Bundesamt für Sport, BASPO.

Manz, K., Schlack, R., Poethko-Müller, C., Mensink, G., Finger, J. \& Lampert, T. (2014). Körperlichsportliche Aktivität und Nutzung elektronischer Medien im Kindes- und Jugendalter. Ergebnisse der KiGGS-Studie - Erste Folgebefragung (KiGGS Welle 1). Bundesgesundheitsblatt - Gesundheitsforschung-Gesundheitsschut\%. 57, 840-848.

Norges Idrettsforbund (2017), Nokkeltall - rapport 2016. Available: https://www.idrettsforbundet.no/contentassets/e7edfa47f77e457abf83827d39c3e1d8/nokkeltallsrapport2016.pdf. Accessed October 12th 2018.

Statistics Norway, (31.08.2014), Folkemengde og befolkningsendringar. Accessed October 12 20018 from https://www.ssb.no/statbank/table/07459

Vaage, O. F. (2009). Mosjon, friluftsliv og kulturaktiviteter. Resultater fra Levekårsunder-søkelsene fra 1997 til 2007. Rapporter 2009/15. Oslo: Statistisk sentralbyrå.

WHO (2009). Percentage of physically active children and adolescents. Available: http://www.euro.who.int/_data/assets/pdf_file/0012/96987/2.4.-Percentage-of physically-active-childrenEDITED_layoutedV2.pdf. Accessed October 12 2018.

WHO (2010). Global Recommendations on Physical Activity for Health, Geneva: World Health Organization.

\section{Authors}

\section{Øyvind Bøthun}

predavatelj, UiT - Arctic Univerza Norveška, Campus Alta, Šola športnih znanosti, Follumsvei 39, 9509 Alta, Norveška e-pošta: oyvind.bothun@uit.no

lecturer, UiT - The Arctic University of Norway, Campus Alta, School of Sport Science, Follumsvei 39, 9509 Alta, Norway e-mail: oyvind.bothun@uit.no

\section{Herbert Zoglowek, PhD}

Profesor, UiT - Arctic Univerza Norveška, Campus Alta, Šola športnih znanosti, Follumsvei 39, 9509 Alta, Norveška e-pošta: herbert.zoglowek@uit.no

Professor, UiT - The Arctic University of Norway, Campus Alta, School of Sport Science, Follumsvei 39, 9509 Alta, Norway e-mail: herbert.zoglowek@uit.no 